\title{
Trend Analyses of Parameters of Equations for Packets Per Distance Achievable in Ubicomp MANETs Using Location- Aware Transmission.
}

\author{
M. Kaleem GALAMALI, Assoc. Prof Nawaz MOHAMUDALLY
}

\begin{abstract}
MANET transmission is one solution to provide networking amenities in ubicomp topographies. If protocols pertaining to this strategy are well designed, it can help in controlling energy issues in ubicomp [77]. The enforcement of location-aware transmission strategies is prone to enhance energy management and hence merits all attention needed from researchers. Among the enhancements awaited [1] are: the application of landbased GPS systems, improved location refresh rates and accuracy, development of better protocols optimised for transmission according to distance criteria and refining the precision of the distance criteria to apply the protocol. The knowledge of distance coverages by transmitted packets in ubicomp and corresponding variations over different node densities, is definitely useful for refining transmission protocols in MANETs. Such an empirical study was made in a previous paper [26], whereby the metric PPD was devised and studied.
\end{abstract}

In this paper, the next study required for metric PPD is forwarded as: "What are the trends of variation observable within each parameter of the equations of curves obtained for metric PPD [26] over varying node densities?" Designers may use the results presented here, towards formulation of better transmission protocols for ubicomp. This piece of research is a follow-up of previous research [1-41].

Key terms: Ubicomp- Ubiquitous Computing, MAUCMobile and Ubiquitous Computing, MANET- Mobile Adhoc Network, CBR- Constant Bit Rate, PPD- Packets Per Distance.

M. Kaleem GALAMALI,

University of Technology Mauritius (student) Mauritius

Assoc. Prof Nawaz Mohamudally University of Technology Mauritius, Mauritius

\section{Introduction}

Ubicomp topographies, especially outdoor ones, may be deficiently equipped with networking devices. Different topographies may demonstrate quite a lot of heterogeneity as concerns accuracy level of distance measurement, location refresh rates and level of performance of existing protocols. MANET transmission may be the undisputed choice for such circumstances. This may be coupled with location- aware transmission. Several ways of studying the resulting Packet Per Distance coverages in ubicomp for most optimal protocol performances. One such method was explained [26], in which the behaviour of metric PPD was portrayed as split into two:

- Previous to peak values, linear tendency is visible:

$$
\mathrm{F}(\mathrm{x})=\mathrm{d} \star \mathrm{x}+\mathrm{f}
$$

- As from the peak value onwards, the exponentially trend is visible:

$$
G(x)=a * \exp (b *(x-c))
$$

Here, the equations of the model have necessitated 5 parameters: $a, b, c, d$ and $f$. the next outcome required for metric PPD is to devise the model equations for the parameters of the equations specified above.

The key contributions of this paper is the development of the trend of variation for each parameter of the equations which are constituents of the model for metric PPD presented previously [26] from which tables 1(a) and 1(b) are re-used here. The empirical methods produced here, may be implemented into software simulators, producing a utility welcome by designers for more fruitful investigations of the evolution and predictability of distance considerations in future ubicomp. The rest of this paper is organised as follows: section 2- Parameter Trend Analysis- Metric PPD, section 3- Conclusion and References.

\section{Parameter Trend Analysis - Metric PPD.}

\subsection{General Procedure Adopted.}

The initial logical step is to plot the tabulated data for each parameter of the equations for the model for PPD onto gnuplot. The step that must follow is the graphical analyses and relating the general observations feasible. As third step, different equations of fits are experimented. Choice of best fit is made based on least reduced chi-square values and most acceptable extendability at node numbers 80, 100 and 120 . Obviously, the conclusive step is to document the corresponding parameter values for each PPD parameter equation. 


\subsection{Trend Analysis - PPD parameter " $a$ ".}

Generally, trend observed is increasing at a decreasing rate. This is characteristics of logarithmic increase.

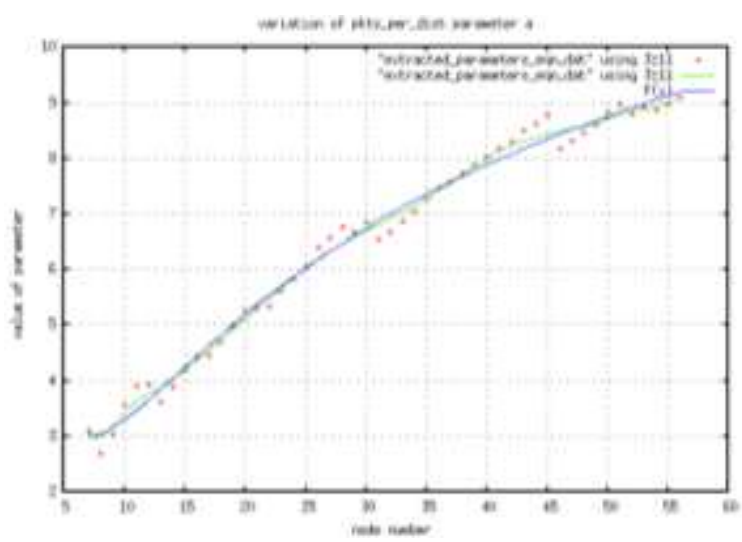

Figure 1: PPD parameter a

The potentially applicable equations of trend are:

$$
\begin{array}{rl}
\text { 1. } F(x)=d * x+f & \\
\text { Ch_sq }=0.144304 & F(80)=12.905777 \\
F(100)=15.518437 & F(120)=18.131096
\end{array}
$$

2. $F(x)=a * \log (b * x)+c$

$$
\text { Ch_sq }=0.113519 \quad \mathrm{~F}(80)=10.181776
$$$$
\mathrm{F}(100)=10.937411 \quad \mathrm{~F}(120)=11.554810
$$

3. $F(x)=a * \log ((b * x)+c)+d$

Ch_sq $=0.0545421 \quad \mathrm{~F}(80)=10.997625$

$\mathrm{F}(100)=12.113825 \quad \mathrm{~F}(120)=13.052908$

4. $F(x)=a * x * \log ((b * x)+c)+d$

Ch_sq $=0.159503 \quad \mathrm{~F}(80)=13.1818$

$\mathrm{F}(100)=16.090719 \quad \mathrm{~F}(120)=19.068241$

5. $F(x)=a * x^{0.5} \star \log ((b \star x)+c)+d$

Ch_sq $=0.0715489 \quad \mathrm{~F}(80)=11.443461$

$\mathrm{F}(100)=12.980736 \quad \mathrm{~F}(120)=14.397010$

6. $F(x)=a * x^{-0.5} \star \log ((b * x)+c)+d$

Ch_sq $=0.0446797 \quad \mathrm{~F}(80)=10.593166$

$\mathrm{F}(100)=11.425430 \quad \mathrm{~F}(120)=12.082897$

7. $F(x)=a * x^{-1} * \log ((b * x)+c)+d$

Ch_sq $=0.0435247 \quad \mathrm{~F}(80)=10.463512$

$\mathrm{F}(100)=11.187897 \quad \mathrm{~F}(120)=11.733196$

8. $F(x)=a \star x^{-2} \star \log ((b * x)+c)+d$

Ch_sq $=0.102457 \quad \mathrm{~F}(80)=9.542912$

$\mathrm{F}(100)=9.885648 \quad \mathrm{~F}(120)=10.116236771$

\section{Choice of best fit for PPD parameter a}

The equation in part 7 above has been selected because of both smallest reduced chi-square value obtained and good extendability. The parameters for best fit are:

$\mathrm{a}=-219.302, \mathrm{~b}=0.0944145, \mathrm{c}=0.866839, \mathrm{~d}=$ 16.3041

2.2 Trend Analysis - PPD parameter " $b$ ".
Generally a decreasing tendency at a very slowly decreasing rate is observed. With deeper observation, it can clearly be noticed that the trend is not a straight line. A very negligible oscillation is also observed.

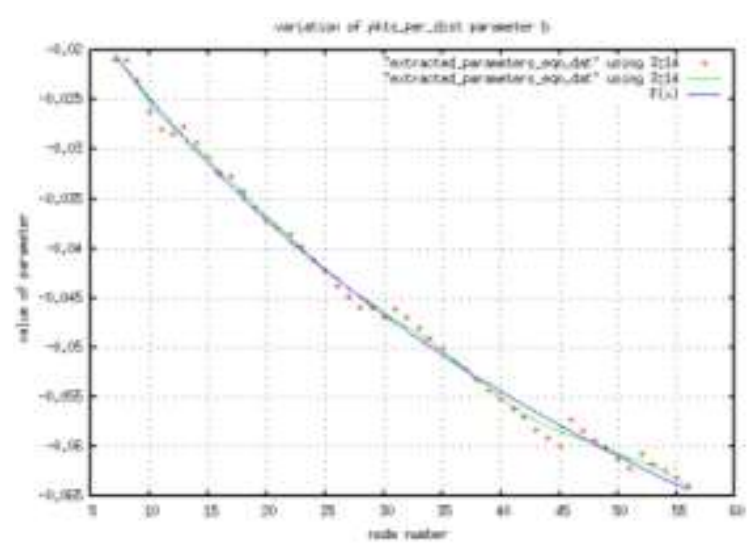

Figure 2: PPD parameter b

The potentially applicable equations of trend are:

$$
\begin{aligned}
& \text { 1. } F(x)=d * x+f \\
& \text { Ch_sq }=4.11842\left(\mathrm{e}^{-06}\right) \quad \mathrm{F}(80)=-0.088337 \\
& \mathrm{~F}(100)=-0.105763 \quad \mathrm{~F}(120)=-0.123189 \\
& \text { 2. } F(x)=(a / \log (x+b))+c \\
& \text { Ch_sq }=9.21784\left(\mathrm{e}^{-07}\right) \quad \mathrm{F}(80)=-0.075545120 \\
& \mathrm{~F}(100)=-0.082686 \quad \mathrm{~F}(120)=-0.088531708 \\
& \text { 3. } F(x)=\left(\left(a * x^{0.5}\right) / \log (x+b)\right)+c \\
& \text { Ch_sq }=1.05935\left(\mathrm{e}^{-06}\right) \quad \mathrm{F}(80)=-0.078397 \\
& \mathrm{~F}(100)=-0.088119 \quad \mathrm{~F}(120)=-0.096901
\end{aligned}
$$

\section{Choice of best fit for PPD parameter $b$}

The equation in part 2 above has been selected because of both smallest reduced chi-square value obtained and good extendability. The parameters for best fit are:

$a=1.10916, b=41.099, c=-0.306784$

\subsection{Trend Analysis - PPD parameter " $C$ ".}

Generally, an increasing trend at a decreasing rate is observed with a non-uniform oscillation.

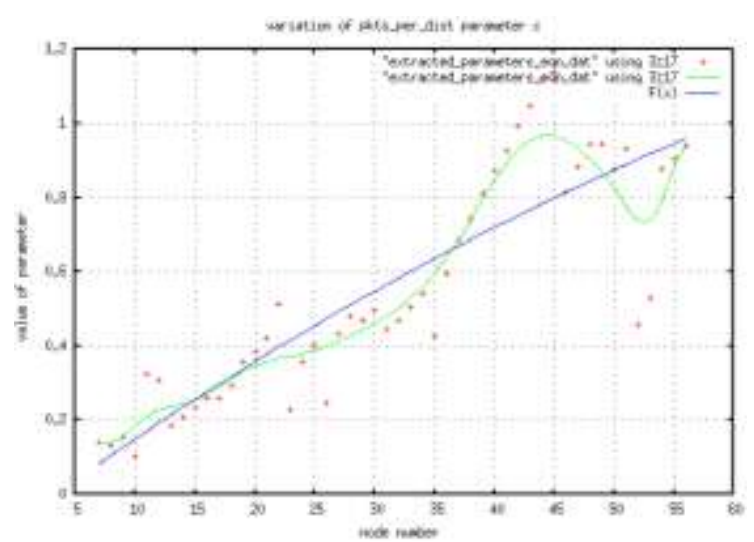

Figure 3: PPD parameter c 
The potentially applicable equations are given below:

$$
\begin{aligned}
& \text { 1. } F(x)=a * \exp ((b * x)+c)+d \\
& \text { Ch_sq }=0.024072 \quad \mathrm{~F}(80)=1.465150 \\
& \mathrm{~F}(100)=1.872295 \quad \mathrm{~F}(120)=2.298488 \\
& \text { 2. } F(x)=a \star x \star \exp ((b \star x)+c)+d \\
& \text { Ch_sq }=0.023517 \quad \mathrm{~F}(80)=1.249998 \\
& \mathrm{~F}(100)=1.435847 \quad \mathrm{~F}(120)=1.578478 \\
& \text { Ch_sq }=0.022283 \quad \mathrm{~F}(80)=1.029582 \\
& \mathrm{~F}(100)=0.968668 \quad \mathrm{~F}(120)=0.844939 \\
& \text { Ch_sq }=0.0236471 \quad \mathrm{~F}(80)=1.288117 \\
& \mathrm{~F}(100)=1.516645 \quad \mathrm{~F}(120)=1.712207
\end{aligned}
$$

\section{Choice of best fit for PPD parameter $c$}

The equation in part 2 above has been selected because of both smallest reduced chi-square value obtained and good extendability. The parameters for best fit are:

$\mathrm{a}=0.0220885, \mathrm{~b}=-0.00462372, \mathrm{c}=0.0867869$, $\mathrm{d}=-0.0813856$

\subsection{Trend Analysis - PPD parameter " $d$ ".}

Generally, the trend is increasing mostly linearly with a slight oscillation. Linear fit has been better than exponential or logarithmic fits.

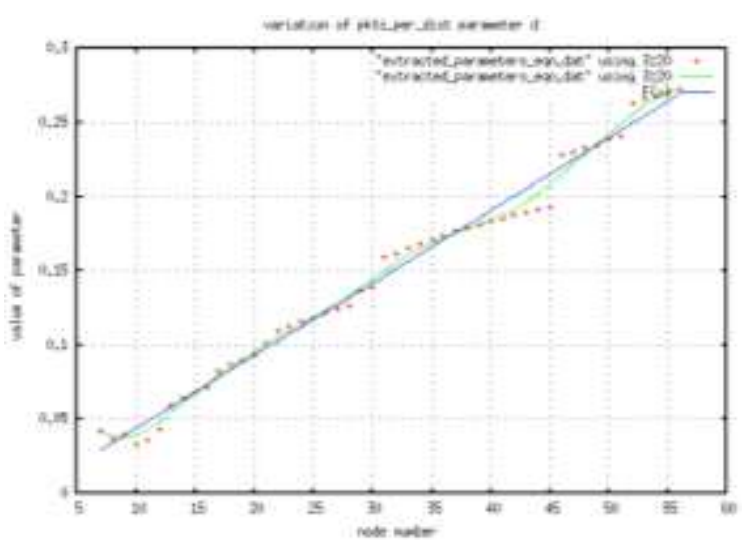

Figure 4: PPD parameter $d$

The potentially applicable equations of trend are:

$$
\begin{aligned}
& \text { 1. } F(x)=a * x+b \\
& \text { Ch_sq }=6.71786\left(\mathrm{e}^{-05}\right)
\end{aligned}
$$

$$
\begin{aligned}
& \text { Ch_sq }=6.99912\left(\mathrm{e}^{-05}\right) \quad \mathrm{F}(80)=0.408079 \\
& \mathrm{~F}(100)=0.531949 \quad \mathrm{~F}(120)=0.668276 \\
& 5 \cdot F(x)=(a / \log ((b * x)+c))+d \\
& \text { Ch_sq }=7.7155\left(\mathrm{e}^{-05}\right) \quad \mathrm{F}(80)=0.366605 \\
& \mathrm{~F}(100)=0.444234 \quad \mathrm{~F}(120)=0.516388
\end{aligned}
$$

\section{Choice of best fit for PPD parameter $d$}

The equation in part 1 above has been selected because of both smallest reduced chi-square value obtained and good extendability. The parameters for best fit are:

$$
a=0.00490731, b=-0.00536143
$$

\subsection{Trend Analysis - PPD parameter " $f$ ".}

Generally, the trend is an oscillation along an axis which is itself increasing at a decreasing rate.

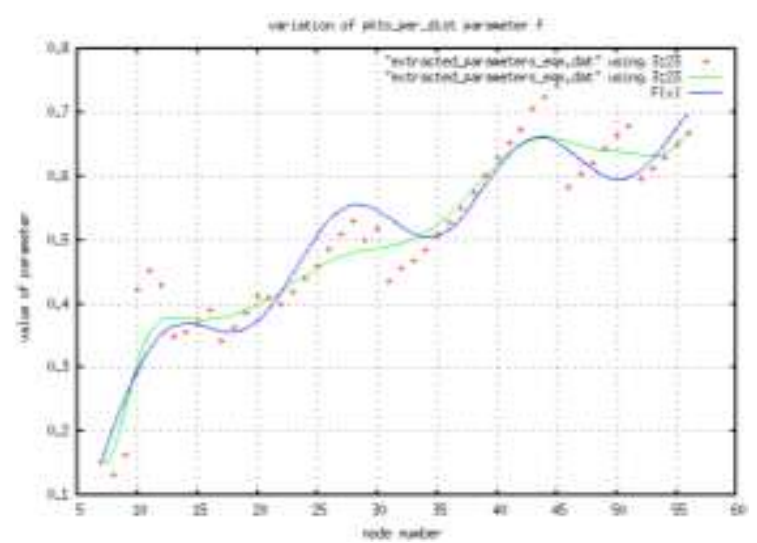

Figure 5: PPD parameter $f$

The potentially applicable equations of trend are:

$$
\begin{array}{cc}
\text { 1. } F(x)=a \star \sin ((b * x)+c)+d \star x+f \\
\text { Ch_sq }=0.0032329 & F(80)=0.902465943 \\
F(100)=1.109852 & F(120)=1.359131576 \\
\text { 2. } F(x)=a \star x+b & \\
\text { Ch_sq }=0.00433145 & F(80)=0.925287 \\
F(100)=1.100079 & F(120)=1.274871 \\
\text { 3. F (x) }=a \star \sin ((b * x)+c)+d * \log (x)+f \\
\text { Ch_sq }=0.00267833 & F(80)=0.721350 \\
F(100)=0.784592 & F(120)=0.905128
\end{array}
$$

\section{Choice of best fit for PPD parameter $f$}

The equation in part 3 above has been selected because of both smallest reduced chi-square value obtained and good extendability. The parameters for best fit are:

$\mathrm{a}=0.0519798, \mathrm{~b}=0.402748, \mathrm{c}=3.13885, \mathrm{~d}=$ $0.241553, \mathrm{f}=-0.299812$

\section{Conclusion.}

This investigation attempt was aimed at and has developed applicable models of trends of the 
parameters of equations for the metric PPD in a MANET topography of $300 \times 300 \mathrm{~m}^{2}$. The models illustrated in this paper consist of mathematical equations of differing complexity. Such knowledge may lead researchers and designers towards producing processing algorithms to be applied in simulator packages for more refined studies of MANETs. This experiment was carried out in gnuplot. Criteria for designating best fit has remained value of least reduced chi-square and most admissible extendability experienced at higher node numbers.

The candid assumptions mentioned in previous paper [26] are re-exercised here. Gnuplot is also believed as sufficiently powerful for the purpose of this study.

Further work recognised here are: formulating an appropriate method of predictability for metric PPD and its trend and reporting specific observations of selected critical values.

\section{References}

[1] M. Kaleem GALAMALI, Assoc. Prof Nawaz MOHAMUDALLY, Towards Dependable Pervasive Systems-A Position and Vision Paper, CEET 2014

[2] M. Kaleem GALAMALI, Assoc. Prof Nawaz MOHAMUDALLY, Model of Energy Savings achievable with Location-aware Node-to-Node Transmission in UbiComp , CEET 2014

[3] M. Kaleem GALAMALI, Assoc. Prof Nawaz MOHAMUDALLY, Model of Energy Savings achievable with Location-aware Node-to-Node Transmission in UbiComp Using Location Refresh Intervals, CEET 2014

[4] M. Kaleem GALAMALI, Assoc. Prof Nawaz MOHAMUDALLY, Model of Energy Savings achievable with Location-aware Transmission in UbiComp Using Relays, CEET 2014

[5] M. Kaleem GALAMALI, Assoc. Prof Nawaz MOHAMUDALLY, Mathematical modeling of need of exact number of relays to ensure seamless mobility in mobile computing, CEET 2014

[6] M. Kaleem GALAMALI, Assoc. Prof Nawaz MOHAMUDALLY, Modelling of need for multiple relays for ensuring seamless mobility, CEET 2014

[7] M. Kaleem GALAMALI, Assoc. Prof Nawaz MOHAMUDALLY, Investigation of prominence of placements of relays in a ubicomp topography,

[8] M. Kaleem GALAMALI, Assoc. Prof Nawaz MOHAMUDALLY, Model of energy savings achievable with location-aware transmission in ubicomp using optimised number of relays.

[9] M. Kaleem GALAMALI, Assoc. Prof Nawaz MOHAMUDALLY, Investigation of Prominence of Placements of Optimised Number of Relays in a Ubicomp Topography using Location-Aware Transmission, CEET 2015.

[10] M. Kaleem GALAMALI, Assoc. Prof Nawaz MOHAMUDALLY, Extending Node Battery Availability in Ubicomp with Location-Aware Transmission, CEET 2015.

[11] M. Kaleem GALAMALI, Assoc. Prof Nawaz MOHAMUDALLY, Extending Node Battery Availability in Ubicomp with Location-Aware Transmission using Location Refresh Intervals, CEET 2015.

[12] M. Kaleem GALAMALI, Assoc. Prof Nawaz MOHAMUDALLY, Extending Node Battery Availability in
Ubicomp with Location-Aware Transmission using Uniformly Placed Relays, CEET 2015.

[13] M. Kaleem GALAMALI, Assoc. Prof Nawaz MOHAMUDALLY, Extending Node Battery Availability in Ubicomp with Location-Aware Transmission Using Optimally Placed Relays, CEET 2015.

[14] M. Kaleem GALAMALI, Assoc. Prof Nawaz MOHAMUDALLY, Model of Sender Node Energy Savings Achievable with Location-Aware MANET Transmission in Ubicomp. ACCN 2016

[15] M. Kaleem GALAMALI, Assoc. Prof Nawaz MOHAMUDALLY, Model of Overall Node Energy Savings Achievable with Location-Aware MANET Transmission in Ubicomp. ACCN 2016

[16] M. Kaleem GALAMALI, Assoc. Prof Nawaz MOHAMUDALLY, Model of Sender Node Extra Energy Savings Achievable in MANET Against Direct Node-toNode Transmission Using Location-Aware Transmission in Ubicomp. ACCN 2016

[17] M. Kaleem GALAMALI, Assoc. Prof Nawaz MOHAMUDALLY, Model of Overall Node Extra Energy Savings Achievable in MANET against Direct Node-toNode Transmission Using Location-Aware Transmission in Ubicomp. ACCN 2016

[18] M. Kaleem GALAMALI, Assoc. Prof Nawaz MOHAMUDALLY, Model of Energy Consumption Ratio Achievable in MANET Using Location-Aware Transmission in Ubicomp. ACCN 2016

[19] M. Kaleem GALAMALI, Assoc. Prof Nawaz MOHAMUDALLY, Model of Minimum Energy Consumption Ratio Achievable in MANET Using LocationAware Transmission in Ubicomp. ACCN 2016

[20] M. Kaleem GALAMALI, Assoc. Prof Nawaz MOHAMUDALLY, Model of Maximum Energy Consumption Ratio Achievable in MANET Using LocationAware Transmission in Ubicomp. ACCN 2016

[21] M. Kaleem GALAMALI, Assoc. Prof Nawaz MOHAMUDALLY, Model of Overall Energy Consumption Fairness Ratio Achievable in MANET Using LocationAware Transmission in Ubicomp. ACCN 2016

[22] M. Kaleem GALAMALI, Assoc. Prof Nawaz MOHAMUDALLY, Model of Overall Energy Consumption Fairness Proportion Achievable in MANET Using LocationAware Transmission for Ubicomp, CEET 2016

[23] M. Kaleem GALAMALI, Assoc. Prof Nawaz MOHAMUDALLY, Model of Minimum Fairness Proportion Achievable in MANET Using Location-Aware Transmission for Ubicomp, CEET 2016

[24] M. Kaleem GALAMALI, Assoc. Prof Nawaz MOHAMUDALLY, Model of Maximum Fairness Proportion Achievable in MANET Using Location-Aware Transmission for Ubicomp, CEET 2016

[25] M. Kaleem GALAMALI, Assoc. Prof Nawaz MOHAMUDALLY, Model of Sender Fairness Proportion Achievable in MANET Using Location-Aware Transmission for Ubicomp, CEET 2016

[26] M. Kaleem GALAMALI, Assoc. Prof Nawaz MOHAMUDALLY, Model of Distance Travelled by packets in MANETs using Location-Aware Transmission for Ubicomp, CEET 2016

[27] M. Kaleem GALAMALI, Assoc. Prof Nawaz MOHAMUDALLY, Model of Maximum CBR Distance Travelled by packets in MANETs using Location-Aware Transmission for Ubicomp, CEET 2016

[28] M. Kaleem GALAMALI, Assoc. Prof Nawaz MOHAMUDALLY, Model of Minimum CBR Distance Travelled by packets in MANETs using Location-Aware Transmission for Ubicomp, CEET 2016

[29] M. Kaleem GALAMALI, Assoc. Prof Nawaz MOHAMUDALLY, Model of Range CBR Distance Experienced by Transmissions in MANETs using LocationAware Transmission for Ubicomp, CEET 2016

[30] M. Kaleem GALAMALI, Assoc. Prof Nawaz MOHAMUDALLY, Trend Analyses of Parameters of Equations for Sender Node Energy Savings Achievable in ubicomp MANETs using Location-Aware Transmission, ACCN 2017.

[31] M. Kaleem GALAMALI, Assoc. Prof Nawaz 
MOHAMUDALLY, Trend Analyses of Parameters of Equations for Overall Node Energy Savings Achievable in ubicomp MANETs using Location-Aware Transmission, ACCN 2017.

[32] M. Kaleem GALAMALI, Assoc. Prof Nawaz MOHAMUDALLY, Trend Analyses of Parameters of Equations for Sender Node Extra Energy Savings Achievable in MANET against Direct Node-to-Node Location-Aware Transmission, ACCN 2017

[33] M. Kaleem GALAMALI, Assoc. Prof Nawaz MOHAMUDALLY, Trend Analyses of Parameters of Equations for Overall Nodes Extra Energy Savings Achievable in MANET against Direct Node-to-Node Location-Aware Transmission, ACCN 2017.

[34] M. Kaleem GALAMALI, Assoc. Prof Nawaz MOHAMUDALLY, Trend Analyses of Parameters of Equations for Energy Consumption Ratio Achievable in Ubicomp MANET Using Location-Aware Transmission, ACCN 2017.

[35] M. Kaleem GALAMALI, Assoc. Prof Nawaz MOHAMUDALLY, Trend Analyses of Parameters of Equations for Minimum Energy Consumption Ratio Achievable in Ubicomp MANETs Using Location-Aware Transmission, ACCN 2017.

[36] M. Kaleem GALAMALI, Assoc. Prof Nawaz MOHAMUDALLY, Trend Analyses of Parameters of Equations for Maximum Energy Consumption Ratio Achievable in Ubicomp MANETs Using Location-Aware Transmission, ACCN 2017.

[37] M. Kaleem GALAMALI, Assoc. Prof Nawaz MOHAMUDALLY, Trend Analyses of Parameters of Equations for Overall Fairness Ratio Achievable in Ubicomp MANETs Using Location-Aware Transmission, ACCN 2017.

[38] M. Kaleem GALAMALI, Assoc. Prof Nawaz MOHAMUDALLY, Trend Analyses of Parameters of Equations for Energy Consumption Fairness Proportion Achievable in Ubicomp MANETs Using Location-Aware Transmission, CEET 2017

[39] M. Kaleem GALAMALI, Assoc. Prof Nawaz MOHAMUDALLY, Trend Analyses of Parameters of Equations for Minimum Fairness Proportion Achievable in Ubicomp MANETs Using Location-Aware Transmission, CEET 2017

[40] M. Kaleem GALAMALI, Assoc. Prof Nawaz MOHAMUDALLY, Trend Analyses of Parameters of Equations for Maximum Fairness Proportion Achievable in Ubicomp MANETs Using Location-Aware Transmission, CEET 2017

[41] M. Kaleem GALAMALI, Assoc. Prof Nawaz MOHAMUDALLY, Trend Analyses of Parameters of Equations for Sender Fairness Proportion Achievable in Ubicomp MANETs Using Location-Aware Transmission, CEET 2017

[42] Markus Bylund and Zary Segall, Towards seamless mobility with personal servers, 2004.

[43] Masugi Inoue, Mikio Hasegawa, Nobuo Ryoki and Hiroyuki Morikawa, Context-Based Seamless Network and Application Control, 2004

[44] Xiang Song, Umakishore Ramachandran, MobiGo: A Middleware for Seamless Mobility, College of Computing Georgia Institute of Technology, Atlanta, GA, USA, August 2007

[45] Budzisz, Ferrús, R., Brunstrom A., Grinnemo, K, Fracchia, R., Galante, G., and Casadevall, F. Towards transport-layer mobility: Evolution of SCTP multihoming, March 2008

[46] Paul Dourish \& Genevieve Bell, Divining a digital future, 2011.

[47] Xiang Song, Seamless Mobility In Ubiquitous Computing Environments, $\mathrm{PhD}$ Thesis, Georgia Institute of Technology, August 2008

[48] Kevin O Mahony, Jian Liang, Kieran Delaney, User-Centric Personalization and Autonomous Reconfiguration Across Ubiquitous Computing Environments, NIMBUS Centre Cork Institute of Technology, Cork, Ireland, UBICOMM 2012

[49] Pablo Vidales, Seamless mobility in 4G systems, Technical Report, University of Cambridge, Computer Laboratory, Number 656, November 2005

[50] João Pedro Sousa and David Garlan, Aura: An Architectural
Framework for User Mobility in Ubiquitous Computing Environments, School of Computer Science, Carnegie Mellon University, USA, August 2002

[51] Dennis Lupiana, Ciaran O'Driscoll, Fredrick Mtenzi, Defining Smart Space in the Context of Ubiquitous Computing, Dublin Institute of Technology, Ireland, Special Issue on ICIT 2009 Conference - Web and Agent Systems, 2009

[52] N.S.V.Shet1, Prof.K.Chandrasekaran2 and Prof. K.C.Shet3, WAP Based Seamless Roaming In Urban Environment with Wise Handoff Technique, International Journal of UbiComp (IJU), Vol.1, No.4, October 2010

[53] Yipeng Yu Dan He Weidong Hua Shijian Li Yu Qi Yueming Wang Gang Pan, FlyingBuddy2: A Braincontrolled Assistant for the Handicapped, Zhejiang University, UbiComp'12, September 5-8, 2012.

[54] Jing Su, James Scott, Pan Hui, Jon Crowcroft, Eyal de Lara Christophe Diot, Ashvin Goel, Meng How Lim, and Eben Upton, Haggle: Seamless Networking for Mobile Applications, 2007

[55] Rui Han, Moustafa M. Ghanem, Li Guo, Yike Guo*, Michelle Osmond, Enabling cost-aware and adaptive elasticity of multi-tier cloud applications, Future Generation Computer Systems, 2012

[56] Byrav Ramamurthy, K. K. Ramakrishnan, Rakesh K. Sinha, Cost and Reliability Considerations in Designing the NextGeneration IP over WDM Backbone Networks, 2012.

[57] Bhavish Aggarwal, Aditya Akella, Ashok Anand, Athula Balachandran, Pushkar Chitnis, Chitra Muthukrishnan, Ram Ramjee and George Varghese, EndRE: An End-System Redundancy Elimination Service for Enterprises, NSDI 2010, San Jose, CA

[58] Ashok Anand, Vyas Sekar and Aditya Akella, SmartRE: An Architecture for Coordinated Network-wide Redundancy Elimination, SIGCOMM 2009, Barcelona, Spain

[59] John Breeden II, "Smart-phone battery life could double without better batteries", Nov 14, 2012

[60] Andy Boxall, "When will your phone battery last as long as your kindle", December 5, 2012.

[61] Imielinski, T. and Navas, J.C. (1999). GPS-based geographic addressing, routing, and resource discovery. Comms. ACM, Vol. 42, No. 4, pp. 86-92.

[62] Hightower, J. and Borriello, G. (2001). Location Systems for Ubiquitous Computing. IEEE Computer, Vol. 34, No. 8, August, pp. 57-66.

[63] Harter, A., Hopper, A., Steggles, P., Ward, A. and Webster, P. (2002). The Anatomy of a Context-Aware Application. Wireless Networks, Vol. 8, No. 2-3, Mar-May, pp. 187-197.

[64] Hightower, J., Brumitt, B. and Borriello, G. (2002). The Location Stack: A Layered Model for Location in Ubiquitous Computing. Proceedings of the 4th IEEE Workshop on Mobile Computing Systems \& Applications (WMCSA 2002), Callicoon, NY, USA, June, pp. 22-28.

[65] Graumann, D., Lara, W., Hightower, J. and Borriello, G. (2003). Real-world implementation of the Location Stack: The Universal Location Framework. Proceedings of the 5th IEEE Workshop on Mobile Computing Systems \& Applications (WMCSA 2003), Monterey, CA, USA, October, pp. $122-128$

[66] Ko, Y., \& Vaidya, N. H. (2000). Location-aided routing (LAR) in mobile ad hoc networks. Wireless Networks, 6(4), 307-321.

[67] Liao, W.-H., Tseng, Y.-C., \& Sheu, J.-P. (2001). GRID: a fully location-aware routing protocol for mobile ad hoc networks. Telecommunication Systems, 18(1), 37-60.

[68] Kuhn, F., Wattenhofer, R., Zhang, Y., \& Zollinger, A. (2003). Geometric ad-hoc routing: of theory and practice. In Proceedings of the ACM (PODC'03) (pp. 63-72).

[69] Jiang, X., \& Camp, T. (2002). Review of geocasting protocols for a mobile ad hoc network. In Proceedings of the Grace Hopper Celebration (GHC).

[70] Ko, Y. \& Vaidya, N. H. (1999). Geocasting in mobile ad hoc networks: location-based multicast algorithms. In 
Proceedings of the IEEE (WMCSA '99) (pp. 101).

[71] Mauve, M., Fuler, H., Widmer, J., \& Lang, T. (2003). Position-based multicast routing for mobile ad-hoc networks (Technical Report TR-03-004). Department of Computer Science, University of Mannheim.

[72] Xu, Y., Heidemann, J., \& Estrin, D. (2001). Geographyinformed energy conservation for adhoc routing. In Proceedings of the ACM/IEEE (MOBICOM'01) (pp. 70-84).

[73] Hu, Y.-C., Perrig, A., \& Johnson, D. (2003). Packet leashes: a defense against wormhole attacks in wireless ad hoc networks. In Proceedings of the INFOCOM' 03 (pp. 19761986).

[74] Patwari, N., Hero III, A. O., Perkins, M., Correal, N. S., \& O'Dea, R. J. (2003). Relative location estimation in wireless sensor networks. IEEE Transactions on Signal Processing, 51(8), 2137-2148

[75] Baldauf, M., Dustdar, S., \& Rosenberg, F. (2007). A Survey on Context Aware Systems. International Journal of Ad Hoc and Ubiquitous Computing, Inderscience Publishers. forthcoming. Pre-print from: http://www.vitalab.tuwien.ac.at/ florian/papers/ijahuc2007.pdf

[76] Hong, D., Chiu, D.K.W., \& Shen, V.Y. (2005). Requirements elicitation for the design of context-aware applications in a ubiquitous environment. In Proceedings of ICEC'05 (pp. 590-596).

[77] Neeraj Tantubay, Dinesh Ratan Gautam and Mukesh Kumar Dhariwal, A Review of Power Conservation in Wireless Mobile Ad hoc Network (MANET)", International Journal of computer Science Issues, Vol 8, Issue 4, No 1, July 2011.

[78] Wenrui Zhao, Mostafa Ammar and Ellen Zegura, "A Message Ferrying Approach for Data Delivery in Sparse Mobile Ad Hoc Networks", MobiHoc'04, May 24-26, 2004, Roppongi, Japan.

About Author (s):

Associate Professor Nawaz Mohamudally works at University of Technology, Mauritius (UTM) and has undertaken supervision of MPhil/PhD Students for many years.

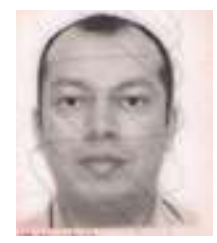

M. Kaleem Galamali is a part-time student (achieved M Phil Transfer on 28.10.2014, currently PhD student) at UTM under supervision of A.P. Nawaz Mohamudally. 